\title{
Performance and Weight Estimates for an Advanced Open Rotor Engine
}

Eric S. Hendricks and Michael T. Tong

Glenn Research Center, Cleveland, Ohio 


\section{NASA STI Program . . . in Profile}

Since its founding, NASA has been dedicated to the advancement of aeronautics and space science. The NASA Scientific and Technical Information (STI) program plays a key part in helping NASA maintain this important role.

The NASA STI Program operates under the auspices of the Agency Chief Information Officer. It collects, organizes, provides for archiving, and disseminates NASA's STI. The NASA STI program provides access to the NASA Aeronautics and Space Database and its public interface, the NASA Technical Reports Server, thus providing one of the largest collections of aeronautical and space science STI in the world. Results are published in both non-NASA channels and by NASA in the NASA STI Report Series, which includes the following report types:

- TECHNICAL PUBLICATION. Reports of completed research or a major significant phase of research that present the results of NASA programs and include extensive data or theoretical analysis. Includes compilations of significant scientific and technical data and information deemed to be of continuing reference value. NASA counterpart of peer-reviewed formal professional papers but has less stringent limitations on manuscript length and extent of graphic presentations.

- TECHNICAL MEMORANDUM. Scientific and technical findings that are preliminary or of specialized interest, e.g., quick release reports, working papers, and bibliographies that contain minimal annotation. Does not contain extensive analysis.

- CONTRACTOR REPORT. Scientific and technical findings by NASA-sponsored contractors and grantees.
- CONFERENCE PUBLICATION. Collected papers from scientific and technical conferences, symposia, seminars, or other meetings sponsored or cosponsored by NASA.

- SPECIAL PUBLICATION. Scientific, technical, or historical information from NASA programs, projects, and missions, often concerned with subjects having substantial public interest.

- TECHNICAL TRANSLATION. Englishlanguage translations of foreign scientific and technical material pertinent to NASA's mission.

Specialized services also include creating custom thesauri, building customized databases, organizing and publishing research results.

For more information about the NASA STI program, see the following:

- Access the NASA STI program home page at http://www.sti.nasa.gov

- E-mail your question to help@sti.nasa.gov

- Fax your question to the NASA STI Information Desk at 443-757-5803

- Phone the NASA STI Information Desk at 443-757-5802

- Write to: STI Information Desk NASA Center for AeroSpace Information 7115 Standard Drive Hanover, MD 21076-1320 


\section{Performance and Weight Estimates for an Advanced Open Rotor Engine}

Eric S. Hendricks and Michael T. Tong

Glenn Research Center, Cleveland, Ohio

Prepared for the

48th Joint Propulsion Conference and Exhibit

cosponsored by the AIAA, ASME, SAE, and ASEE

Atlanta, Georgia, July 30-August 1, 2012

National Aeronautics and

Space Administration

Glenn Research Center

Cleveland, Ohio 44135 


\section{Acknowledgments}

The work presented in this paper was supported by the Subsonic Fixed Wing Project at NASA Glenn Research Center. Special thanks to Jeff Berton and Bill Haller of NASA Glenn Research Center and Mark Guynn of NASA Langley Research Center for their support and guidance in this research. Lastly, the authors would like to thank General Electric for providing access to advanced counter-rotating propeller data in support of this study.

This report contains preliminary findings, subject to revision as analysis proceeds.

Trade names and trademarks are used in this report for identification only. Their usage does not constitute an official endorsement, either expressed or implied, by the National Aeronautics and Space Administration.

This work was sponsored by the Fundamental Aeronautics Program at the NASA Glenn Research Center.

Level of Review: This material has been technically reviewed by technical management.

Available from

NASA Center for Aerospace Information 7115 Standard Drive

Hanover, MD 21076-1320
National Technical Information Service 5301 Shawnee Road Alexandria, VA 22312 


\title{
Performance and Weight Estimates for an Advanced Open Rotor Engine
}

\author{
Eric S. Hendricks and Michael T. Tong \\ National Aeronautics and Space Administration \\ Glenn Research Center \\ Cleveland, Ohio 44135
}

\begin{abstract}
NASA's Environmentally Responsible Aviation Project and Subsonic Fixed Wing Project are focused on developing concepts and technologies which may enable dramatic reductions to the environmental impact of future generation subsonic aircraft. The open rotor concept (also historically referred to an unducted fan or advanced turboprop) may allow for the achievement of this objective by reducing engine fuel consumption. To evaluate the potential impact of open rotor engines, cycle modeling and engine weight estimation capabilities have been developed. The initial development of the cycle modeling capabilities in the Numerical Propulsion System Simulation (NPSS) tool was presented in a previous paper. Following that initial development, further advancements have been made to the cycle modeling and weight estimation capabilities for open rotor engines and are presented in this paper. The developed modeling capabilities are used to predict the performance of an advanced open rotor concept using modern counter-rotating propeller designs. Finally, performance and weight estimates for this engine are presented and compared to results from a previous NASA study of advanced geared and directdrive turbofans.
\end{abstract}

\section{Introduction}

At the outset of the Subsonic Fixed Wing (SFW) Project, NASA established a set of system level environmental metrics as a means to spur technology development to reduce aviation's environmental impact. The goals, as shown in Figure 1, are generational and the metrics, and their respective values, have evolved over time and are relative to a particular baseline vehicle. The current metrics address reducing certification noise, oxides of nitrogen (NOx) emissions in the landing/takeoff (LTO) cycle, NOx emissions during cruise, and aircraft fuel/energy consumption (Ref. 1). The SFW project, NASA's Environmentally Responsible Aviation (ERA) Project, and the FAA's Continuous Lower Energy, Emissions and Noise (CLEEN) program are all developing advanced technologies for reducing the environmental impact of subsonic transport aircraft across the range of future generations. While there is a desire to improve all subsonic aircraft, it is recognized that the benefits of future technologies depend on when those technologies mature to a sufficient Technology Readiness Level as well as on the vehicle size and mission.

To assess propulsion technologies capable of meeting the first generation of goals $(\mathrm{N}+1)$, the SFW systems analysis team has been investigating potential environmental benefits of advanced propulsion systems on an "advanced" single-aisle transport aircraft (ASAT). This aircraft would fall into the same class as the Boeing 737 and Airbus A320. Nominally, the ASAT aircraft would be capable of carrying 162 passengers on a $3250 \mathrm{n} \mathrm{mi}$ flight. To power this aircraft, three types of advanced propulsion systems have been considered in a multiphase, multiyear study conducted by the systems analysis team. During the first 3 years of the study, two types of ultra-high bypass (UHB) turbofan concepts were assessed. These two concept types were the advanced direct-drive turbofan and the geared turbofan. The studies showed potential reductions of 29 percent in fuel burn, 50 percent in LTO NOx emissions and a $25 \mathrm{EPNdB}$ reduction in cumulative noise relative to a late 1990s technology baseline (Ref. 2). 


\begin{tabular}{|c|c|c|c|}
\hline \multirow{2}{*}{\begin{tabular}{c}
\multirow{2}{*}{$\begin{array}{c}\text { TECHNOLOGY } \\
\text { BENEFIT * }\end{array}$} \\
\cline { 2 - 4 }
\end{tabular}} & \multicolumn{3}{|c|}{$\begin{array}{c}\text { TECHNOLOGY GENERATIONS } \\
\text { (Technology Readiness Level = 4-6) }\end{array}$} \\
\hline $\begin{array}{c}\text { Noise } \\
\text { (cum margin rel. to Stage 4) }\end{array}$ & $-32 \mathrm{~dB}$ & $\mathrm{~N}+2\left(\mathbf{2 0 2 0}\right.$ **) $^{*}$ & $\mathrm{N}+3$ (2025) \\
\hline $\begin{array}{c}\text { LTO NOx Emissions } \\
\text { (rel. to CAEP 6) }\end{array}$ & $-60 \%$ & $-42 \mathrm{~dB}$ & $-71 \mathrm{~dB}$ \\
\hline $\begin{array}{c}\text { Cruise NOx Emissions } \\
\text { (rel. to 2005 best in class) }\end{array}$ & $-55 \%$ & $-70 \%$ & $-80 \%$ \\
\hline $\begin{array}{c}\text { Aircraft Fuel/Energy Consumption } \\
\text { (rel. to 2005 best in class) }\end{array}$ & $-33 \%$ & $-50 \%$ & $-60 \%$ \\
\hline
\end{tabular}

* Projected benefits once technologies are matured and implemented by industry. Benefits vary by vehicle size and mission. $\mathrm{N}+1$ and $\mathrm{N}+3$ values are referenced to a 737-800 with CFM56-7B engines, $\mathrm{N}+2$ values are referenced to a 777-200 with GE90 engines

** ERA's time-phased approach includes advancing "long-pole" technologies to TRL 6 by 2015

$\ddagger \mathrm{CO}_{2}$ emission benefits dependent on life-cycle $\mathrm{CO}_{2 \mathrm{e}}$ per $\mathrm{MJ}$ for fuel and/or energy source used

Figure 1.-NASA's technology goals for subsonic transport aircraft (Ref. 1).

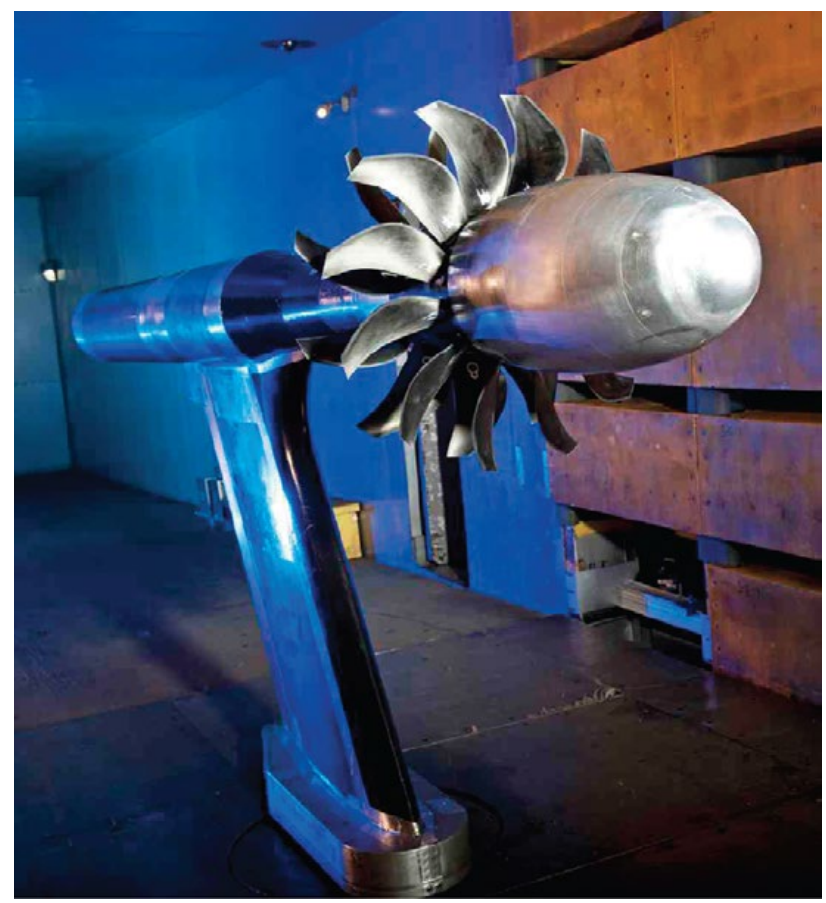

Figure 2.-A scale model of the open rotor being tested in NASA Glenn Research Center's 9- by 15-Ft low speed wind tunnel.

Following several phases of evaluating UHB turbofan concepts, the systems analysis team began investigating the open rotor concept for powering the ASAT aircraft. The open rotor engine concept, shown being tested in Figure 2, was originally developed during the 1970s and 1980s in response to high fuel prices. During that time, NASA's Advanced Turboprop Project (ATP) sponsored research by government, academia and industry to develop advanced propeller configurations. While the technology developed during the ATP never became commercial product, it demonstrated the potential to reduce aircraft fuel consumption by 25 to 30 percent versus aircraft flying at that time (Ref. 3 ). As a result, the ATP team (both NASA and industry partners) received the 1987 Collier Trophy "for developing advanced turboprop propulsion technology for new fuel efficient subsonic aircraft propulsion systems" 
(Ref. 3). With the return of higher fuel costs, the open rotor concept has received renewed interest due to its potential to reduce fuel consumption. Research efforts on developing and testing new open rotor blade designs are ongoing in the United States (Ref. 4) and in Europe(Ref. 5).

In order to evaluate the potential benefits of a modern open rotor engine, the SFW systems analysis team has developed modeling capabilities for assessing this system. Initial capabilities for analyzing the engine performance, aircraft mission and acoustic characteristics have been created for open rotors (Refs. 6 and 7). This paper first presents an overview of the previous cycle modeling developments made for open rotor engines. It then describes recent enhancements made to the cycle modeling capability as well as the development of open rotor engine weight estimation techniques. Next, the cycle and weight modeling techniques described in the paper are used to evaluate an open rotor engine for the ASAT aircraft. Finally, the open rotor engine developed for this application is compared to advanced geared and direct-drive turbofans developed during previous phases of the advanced propulsion study for ASAT aircraft.

\section{Review of Previous Open Rotor Cycle Modeling Developments}

Over the past 3 years, NASA has worked to develop cycle modeling capabilities for open rotor engines within the Numerical Propulsion System Simulation (NPSS) tool (Ref. 8). These modeling improvement efforts have concentrated in four main areas and were presented in a previous paper by the author (Ref. 6). The following sections briefly summarize the relevant modeling developments produced during the first 2 years of this research effort.

\section{Counter-Rotating Propeller Modeling}

The first challenge encountered when creating a cycle model for an open rotor engine was developing a performance prediction modeling capability for the counter-rotating propellers as the traditional propeller element in NPSS was not configured to handle the high speed, counter-rotating propellers. The traditional propeller element could not accept the multiple shaft inputs for the counter-rotating configuration and could not accept performance maps that were a function of freestream Mach number. Therefore, a new component was created for NPSS which would enable analysis of this type of configuration. This component was written in a similar fashion as other NPSS components, with the performance of the counter-rotating propellers being estimated via performance maps. As a result, a wide variety of propeller designs can be modeled by simply replacing the performance map.

The development of this performance analysis capability in NPSS was based on the available information for some of the historic blade sets designed during the ATP. The most complete data set available from the ATP was for the F7/A7 blade geometry (Ref. 9). This scale model blade set was thoroughly tested in wind tunnels and was eventually used in tests of a full scale engine, the GE36 Unducted Fan (UDF) Demonstrator. Using the available data, performance maps were created by fitting the data with a set of second-order response surface equations. These equations captured the relationship between the independent parameters (advance ratio, free stream Mach number and blade pitch angle) and the output power coefficient and thrust coefficient.

\section{Counter-Rotating Turbine Modeling}

During the initial development of the open rotor cycle analysis capability, a power turbine similar to that used in the GE36 UDF Demonstrator was assumed as the most likely configuration. In this architecture, an alternating blade row, counter-rotating turbine was used as shown in Figure 3 (Ref. 10). This type of turbine is unique and required the investigation of modeling techniques that may be able to capture the performance of this type of system. Of the techniques tested, the use of a single traditional turbine component in NPSS was selected as it produced a reasonable representation based on available data from the GE36. 


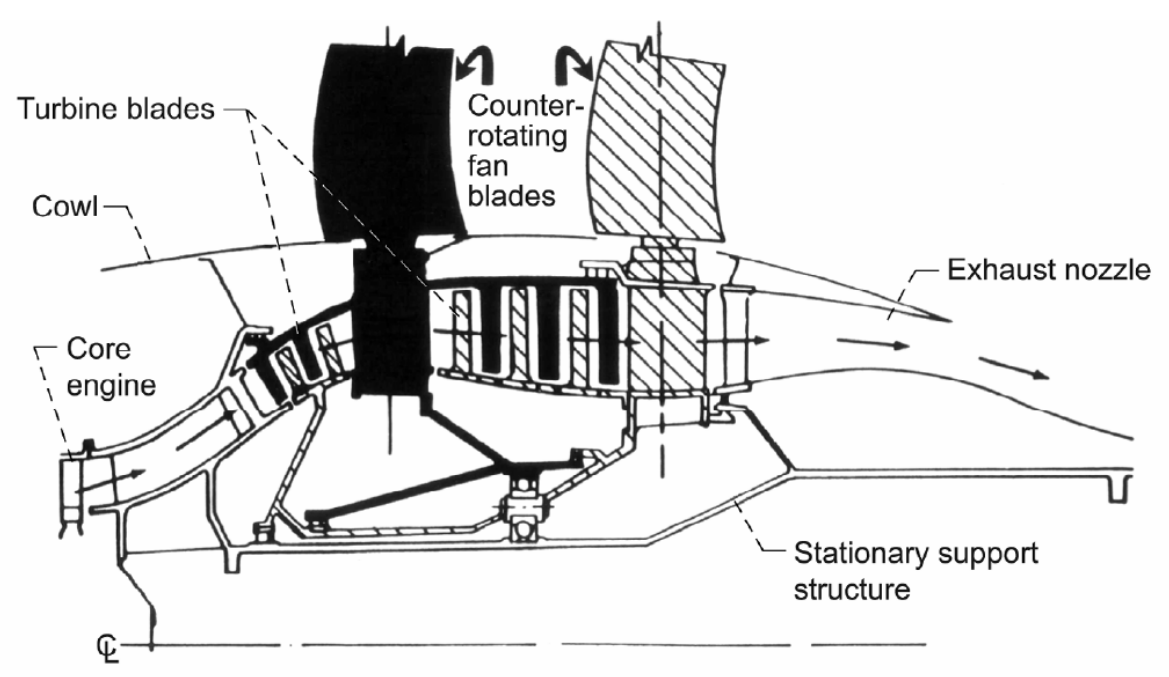

Figure 3.-Schematic of GE36 power turbine (Ref. 10).

\section{Multidesign Point (MDP) Approach}

One of the key components of the initial open rotor modeling development was the implementation of a MDP approach for engine cycle analysis. In this approach, the NPSS engine model was set up such that several operating conditions would be simultaneously used to size the engine. This approach requires some additional implementation time, but results in all engines created during the design process meeting the operating requirements at all flight conditions. During the open rotor model development process, two design points were selected as being critical for the engine sizing process. These two points were a top-ofclimb condition (nominally Mach 0.78 at 35,000 ft, standard day) and a hot day, rolling takeoff condition (Mach 0.25, sea level, International Standard Atmosphere (ISA) $+27^{\circ} \mathrm{F}$ ). By providing thrust targets and operating limits at these two points, an engine cycle can be quickly generated which meets these operating requirements for a given set of component designs and technology level assumptions. Through implementing the MDP approach, the development time for generating engine cycles that meet the aircraft mission needs was greatly reduced.

\section{Power Management Strategy}

Finally, a power management strategy was developed and implemented for the open rotor engine. The power management strategy is important for an open rotor as both the combustor fuel flow and the propeller blade pitch angles could be changed to affect thrust and fuel burn of the engine. From the historic development of the open rotor concept during the Advanced Turboprop Project, very little information was provided about how the engine would be controlled with these two degrees of freedom. Therefore, a control strategy was created during the initial model development in which the blade pitch was varied with freestream Mach number according to a fixed schedule as shown in Figure 4 (Ref. 6). This schedule was selected based on observing the impact of several pitch angles on the engine operation at various flight conditions. By selecting this power management strategy, the engine could easily be evaluated at all operating conditions in the flight envelope. 


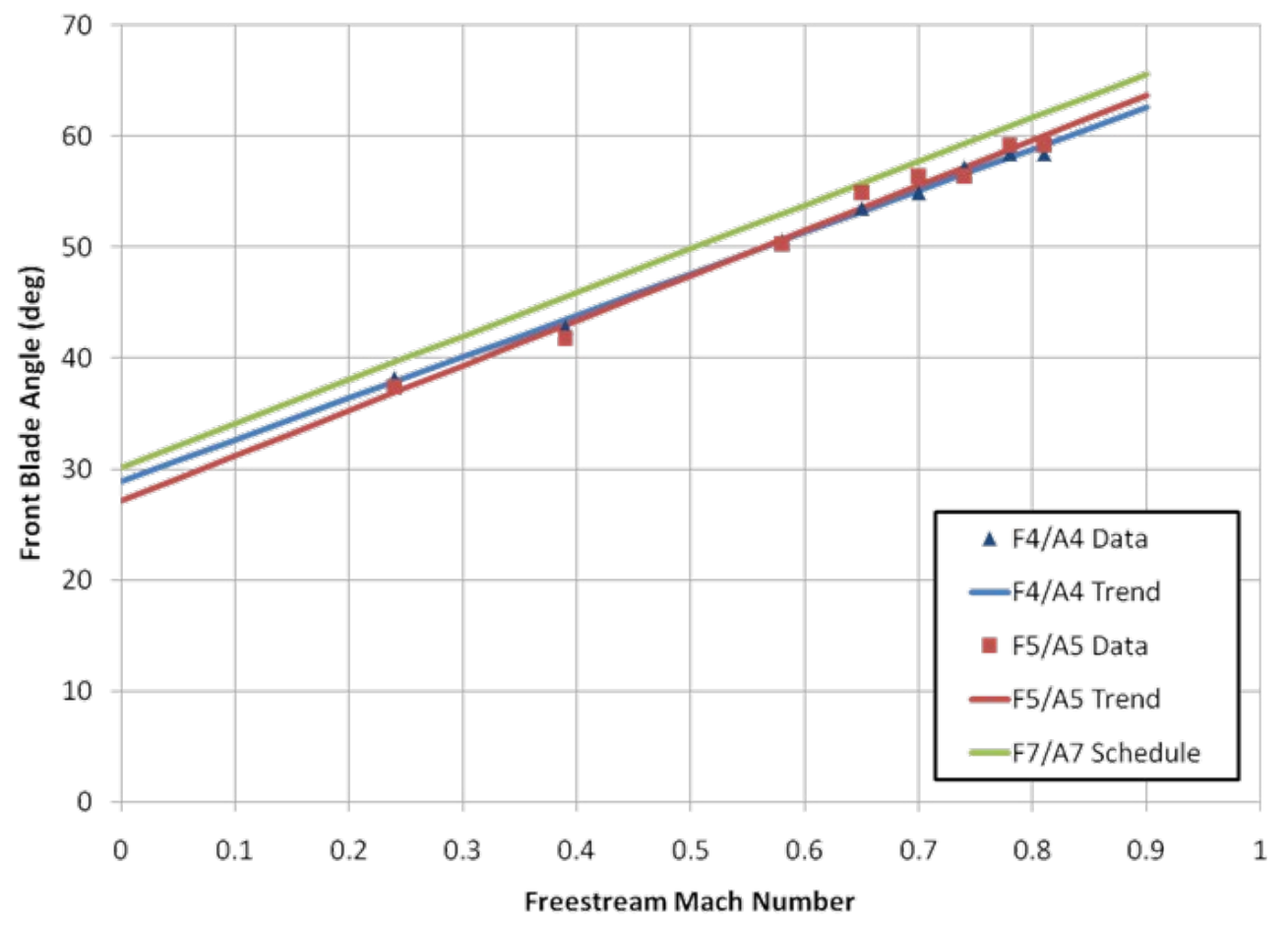

Figure 4.-Front propeller blade angle schedule (Ref. 6).

\section{Open Rotor Modeling Improvements}

The initial modeling developments presented in the previous sections allowed for the cycle analysis of a notional open rotor engine to be completed. However, over the past year a number of improvements have been made to NASA open rotor modeling capabilities which have enhanced the ability to assess future open rotor engines. The following sections briefly summarize the recent modeling developments made for the open rotor which supplement or replace the modeling capabilities described above.

\section{Performance Maps for Modern Counter-Rotating Propellers}

In the initial development of an open rotor engine cycle model described in Reference 6 , the historic F7/A7 counter-rotating propellers were used to generate the performance maps. These propellers were designed during the 1980s as part of the Advanced Turboprop Project and therefore do not accurately estimate performance characteristics of modern blade designs. As a result, new performance maps representative of modern blade designs were needed in order to estimate the benefits of a future open rotor engine.

Over the past few years, NASA and General Electric have been collaborating to design and test advanced open rotor blade geometries (Ref. 11). A multiyear test campaign was conducted in the NASA Glenn Research Center 8- by 6-Ft and 9- by 15-Ft wind tunnel complex that measured both performance and acoustic characteristics of these modern blade designs. From the performance characteristics observed in these tests, performance maps were created following the process described in Reference 6. The performance maps correlate the thrust and power coefficients to advance ratio, free stream Mach number and blade pitch angle using a second order polynomial response surface equation. Using these performance maps in the cycle modeling has enabled the assessment of an advanced open rotor engine system. 


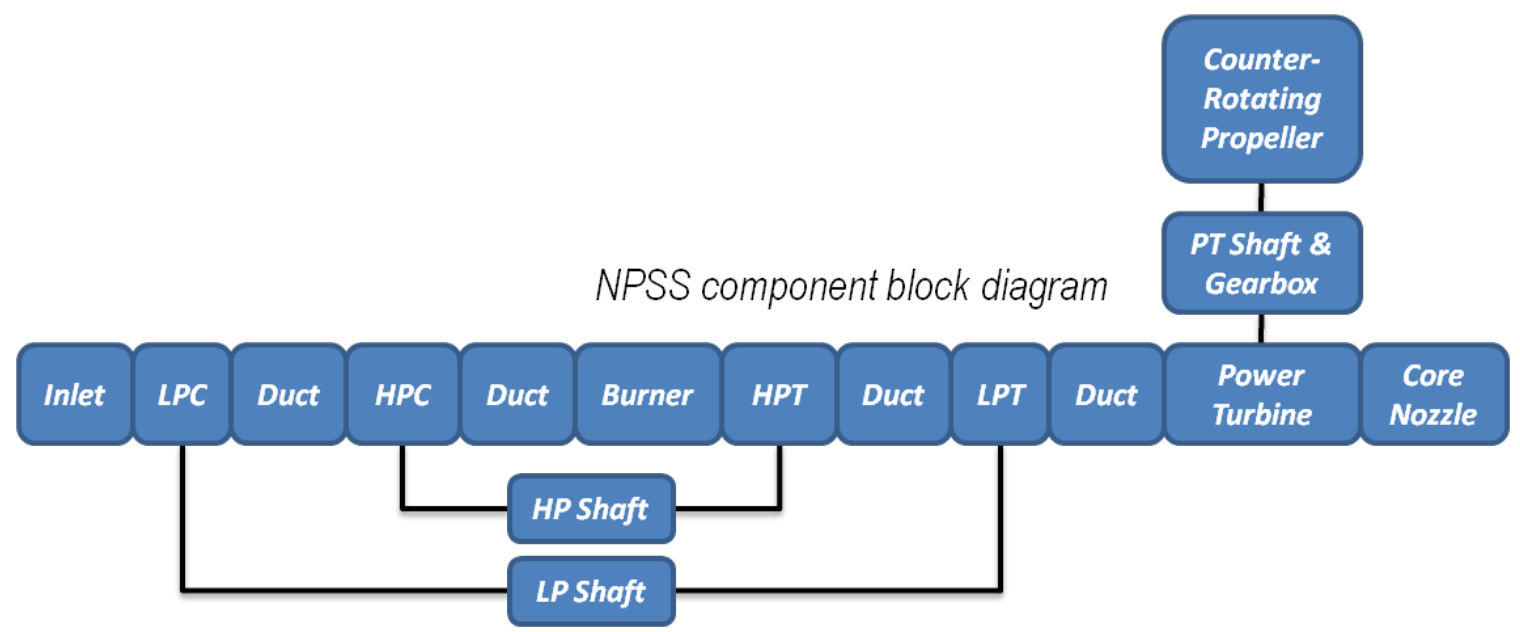

Figure 5.-Geared open rotor engine components.

\section{Geared Open Rotor Architecture}

In the initial development of the open rotor modeling capability, a direct drive architecture with a counter-rotating power turbine was assumed. This configuration eliminates the need for a large, heavy and complex gearbox. However, the direct drive configuration requires that the turbine and propellers rotate at the same speeds. The propellers designed for open rotors are large in diameter and constrained by tip speed, typically resulting in rotational speeds of less than $1100 \mathrm{rpm}$. This relatively slow rotation speed makes designing the turbine difficult as a larger diameter or more stages need to be added to extract enough work from the core flow. Larger diameters and additional stages add more weight to the turbine and the overall engine system. Alternatively, an engine with a gearbox allows the propeller and turbine to each be designed for different rotational speeds. The turbine can be designed to provide the same power at a higher rotation speed with a smaller diameter and fewer stages. This turbine design would be lighter than a counter-rotating turbine meeting the same power requirements and would offset the weight added by the gearbox. In a trade study comparing the geared and direct drive open rotor engines, similar performance levels were achieved with the weight estimate for geared engine slightly lower than the direct drive configuration. This benefit would likely be greater as the open rotor engine grows to higher thrusts. The higher thrust engines would need to have a larger propeller diameter to produce the required thrust and the tip speed limit would result in even slower propeller rotation speeds. Therefore, a cycle model for a geared open rotor engine was pursued for this study as shown in Figure 5. In this configuration, there are two spools composing the gas generator: the low pressure (LP) spool composed of a compressor (LPC) and turbine (LPT) and the high pressure (HP) spool composed of a compressor (HPC) and turbine (HPT). Downstream of the gas generator is a power turbine (PT) which drives the counter-rotating propellers through a gearbox.

\section{Power Management Strategy}

During the initial development of the open rotor cycle modeling capability, a power management strategy was developed which utilized a blade pitch schedule as a function of Mach number. This schedule was required as both the propeller blade pitch angles and fuel flow could be varied to achieve the desired thrust. However, the strategy of holding blade pitch constant at a given Mach number resulted in large changes in propeller speed as the engine thrust was reduced. By comparison, most modern turboprops operate with constant speed propellers. Therefore, a constant tip speed power management strategy was investigated and implemented in the current open rotor model. The constant tip speed power management strategy was implemented in the NPSS cycle model by adding an independent parameter for the blade pitch and a dependent parameter for the tip speed to the solver. Additionally, a minimum blade 


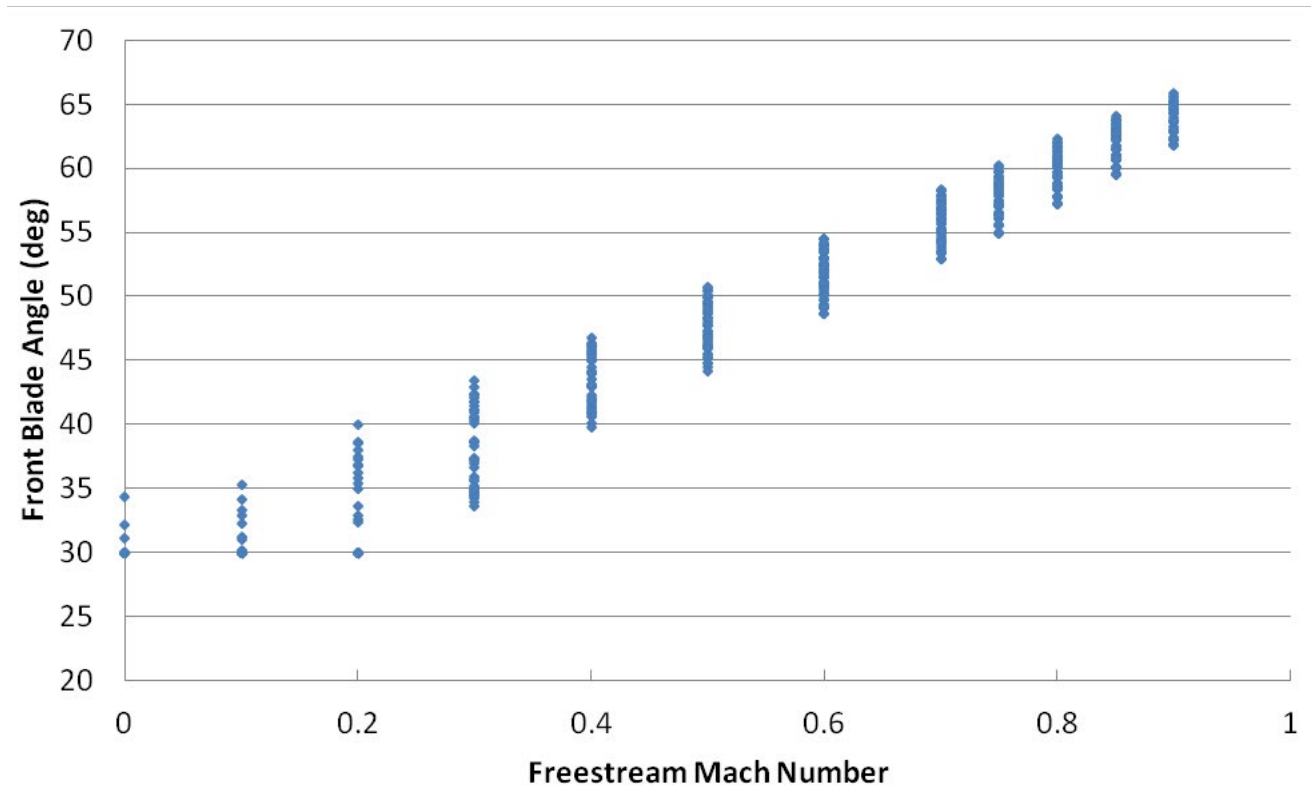

Figure 6.-Blade angle settings for constant tip speed throughout the flight envelope.

angle constraint was applied to prevent the engine from operating at blade angles that were outside the range of validity for the propeller maps. As a result of utilizing the constant tip speed strategy, operating points for the engine were identified for selected flight conditions as shown in Figure 6. In comparison to the previous power management strategy shown in Figure 4, the constant tip speed strategy shown in Figure 6 gives a range of possible blade angles for each flight Mach number. However, the overall trend of blade pitch angle increasing as Mach number increases remains similar to the previous strategy. The new constant tip speed approach also captures other minor factors that impact the blade angle, such as the variations in altitude. Figure 6 can provide further insight into how the blade angles change as the engine thrust is changed at a given flight condition. For the maximum thrust (power) conditions, the blade angle is the largest with the blade angle decreasing by as much as $10^{\circ}$ as the engine throttle is reduced.

\section{Open Rotor Weight Estimation}

Finally, the NASA software tool WATE++ (Weight Analysis of Gas Turbine Engines) (Refs. 12, 13, and 14) was used to create an engine component architecture that would match the engine thermodynamic cycle produced using the methods in the previous sections. The cycle data required for WATE execution, such as airflow, temperatures, and pressures, pressure ratios, etc., were derived from the NPSS cycle model output. The maximum temperature and pressure required for sizing each engine component were identified by predicting the cycle performance throughout the flight envelope. The cycle data, the material properties, and design rules for geometric, stress, and turbomachinery stage-loading limits were used to determine an acceptable engine layout. The material assumed for the LPC and for the first five stages of the HPC is titanium. For the remaining stages of the HPC, a titanium-aluminide alloy is used. Nickelbased alloy is used for all the turbine components. For the counter-rotating propellers, a rotor weight correlation which is a function of maximum power delivered to the rotor, blade tip-speed, and number of blades is used. This correlation assumes the blades are constructed of polymer composites and is described in detail in Reference 15. An empirical correlation was used to calculate the weight of the gearbox and lubrication system as shown in Figure 7. The correlation is a function of maximum delivered output power and gear ratio, and was developed at NASA based on actual gearbox weight data from over fifty rotorcraft, tiltrotors, and turboprop aircraft. 


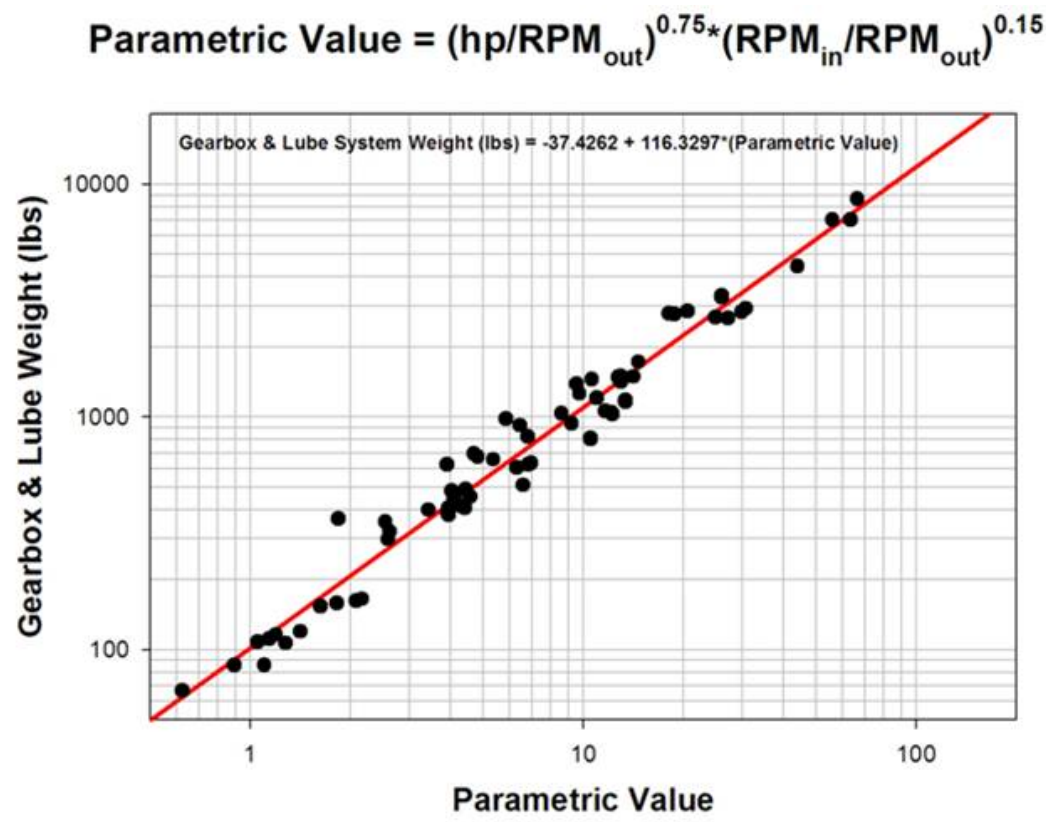

Figure 7.-Gearbox and Lubrication System Weight Correlation.

\section{Open Rotor Modeling Results}

The modeling developments described in the previous sections were used to create an open rotor engine model representative of a future system capable of powering an advanced single aisle transport aircraft. This aircraft is designed to fly $3250 \mathrm{n} \mathrm{mi}$ at a cruise Mach number of 0.78 carrying 162 passengers. The following sections provide an overview of the performance and weight estimates calculated for an open rotor engine based on the described model. Following these sections, the open rotor engine results are compared to advanced geared and direct-drive turbofans which were modeled by NASA as part of a previous study.

\section{Cycle Analysis and Performance Results}

The cycle model was developed using the MDP strategy previously summarized in which two operating conditions were simultaneously used to size the engine components. The two design points selected for this study were a top-of-climb (Mach 0.78 at 35,000 ft) condition and a rolling takeoff (Mach 0.25 at $0 \mathrm{ft}$, ISA $+27^{\circ} \mathrm{F}$ ) condition. At each of these points, thrust requirements and operating limits were specified for the engine. Additionally, performance assumptions were specified for each core component at the top-of-climb (aerodynamic design point) flight condition as shown in Table 1. The component efficiency assumptions listed in the table are consistent assumptions used in a recent NASA study of advanced geared and direct drive turbofans (Ref. 2). However, the pressure ratios of the low pressure and high pressure compressors were adjusted to match the open rotor engine architecture. The LPC pressure ratio was set to 4.2 and the HPC pressure ratio set to 10.0 to give an overall pressure ratio of 42.0 which matches the turbofan study. In addition to the assumptions in Table 1, a gear ratio of 6 and a gearbox efficiency of 99 percent were assumed. Finally, propeller performance assumptions were selected based the propeller design characteristics and data obtained during wind tunnel testing. 
TABLE 1.-OPEN ROTOR ENGINE COMPONENT PERFORMANCE ASSUMPTIONS AT TOP OF CLIMB (M0.78, $35000 \mathrm{ft})$

\begin{tabular}{|l|l|r|}
\hline \multicolumn{1}{|c|}{ Component } & \multicolumn{1}{|c|}{ Parameter } & Value \\
\hline \multirow{2}{*}{ LPC } & Pressure ratio & 4.2 \\
& Adiabatic efficiency, \% & 89.6 \\
\hline \multirow{2}{*}{ HPC } & Pressure ratio & 10.0 \\
& Adiabatic efficiency, \% & 88.6 \\
\hline HPT & Adiabatic efficiency, \% & 91.9 \\
\hline LPT & Adiabatic efficiency, \% & 94.2 \\
\hline Power turbine & Adiabatic efficiency, \% & 94.0 \\
\hline
\end{tabular}

Using MDP methodology and assumptions described above an NPSS cycle model was developed. Table 2 provides a summary of key engine metrics at the two operating points used to design the engine cycle model as well as at sea level static. At the top-of-climb point, $5000 \mathrm{lb}$ of thrust is required by the airplane to achieve service ceiling performance with an overall pressure ratio (OPR) of 42 coming from the component performance assumptions. At the rolling takeoff design point, 17,500 lb of thrust was required to meet field length performance for the aircraft. However, 19,000 lb force of thrust was produced by the engine which exceeded the thrust required by 1,500 lb. The engine exceeded the rolling takeoff thrust required as a result of temperature constraints set in the engine MDP process. These constraints limited the combustor exit temperature at the top-of-climb flight condition to ensure the hot section would operate at lower temperatures during cruise resulting in longer life of the turbines. As a result, the open rotor engine produces excess thrust at the rolling takeoff and sea level static conditions.

TABLE 2.-OPEN ROTOR ENGINE PERFORMANCE FOR MAXIMUM THRUST AT KEY OPERATING CONDITIONS

\begin{tabular}{|l|c|c|c|}
\hline \multicolumn{1}{|c|}{ Performance parameter } & $\begin{array}{c}\text { Top of climb, } \\
\mathrm{M} 0.78,35000 \mathrm{ft}\end{array}$ & $\begin{array}{c}\text { Rolling takeoff, } \\
\mathrm{M} 0.25,0 \mathrm{ft}, \mathrm{ISA}+27^{\circ} \mathrm{F}\end{array}$ & $\begin{array}{c}\text { Sea level static, } \\
\mathrm{M} 0.0,0 \mathrm{ft}, \mathrm{ISA}+27^{\circ} \mathrm{F}\end{array}$ \\
\hline Net thrust, lbf & 5000 & 19000 & 27300 \\
\hline Propeller thrust, lbf & 4830 & 18600 & 26500 \\
\hline TSFC, $\mathrm{lbm} / \mathrm{hr} / \mathrm{lbf}$ & 0.428 & 0.229 & 0.158 \\
\hline OPR & 42.0 & 28.5 & 29.4 \\
\hline Combustor exit temperature, R & 3280 & 3460 & 3460 \\
\hline Core mass flow, lbm/s & 21.8 & 42.7 & 42.2 \\
\hline
\end{tabular}

For all three flight conditions shown in Table 2, a low thrust specific fuel consumption (TSFC) is predicted from the cycle model. The low TSFC is a consequence of having a large portion of the net thrust at each operating condition being produced by the high-efficiency counter-rotating propellers. The low TSFC is a highly desirable characteristic of the open rotor engines and persists throughout the flight envelope. The TSFC characteristics for different throttle settings at the flight conditions of Table 2 are shown in Figure 8.

\section{Weight and Flowpath Estimates}

Following the engine cycle model development, an estimate of the engine weight and flowpath dimensions was developed using the methods described in the previous section. Table 3 gives a summary of the major weights and dimensions of the open rotor engine developed for this study. The overall engine weight is predicted to be over $9,000 \mathrm{lb}$, with about a third of the engine weight coming from the counterrotating propellers. An additional $1000 \mathrm{lb}$ of the engine weight comes from the addition of a gearbox to the engine. Table 3 also lists the estimated overall dimensions of the open rotor engine. The maximum propeller diameter for the engine designed in this study is estimated to be about $13.8 \mathrm{ft}$ with an overall engine length of about $23 \mathrm{ft}$. Additionally, Table 3 presents the estimates for the number of stages for each turbomachinery component and the assumed gear ratio for the gearbox. A notional sketch of the 
flowpath of the open rotor engine developed in this study is shown in Figure 9. The center box between the propeller blades is the location of the gearbox, with the other boxes representing ducts that pass the core flow around the turbine to the core nozzle.

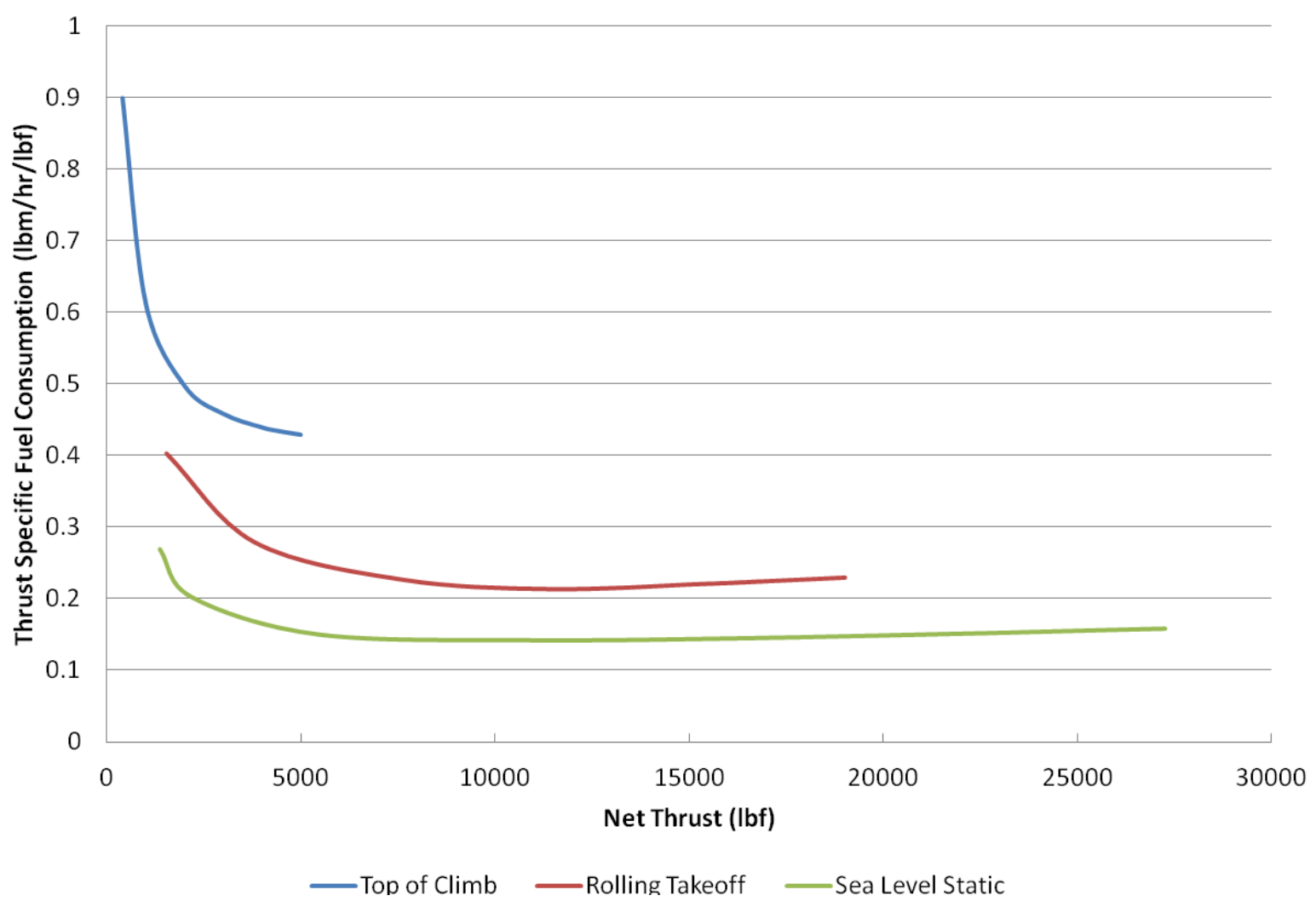

Figure 8. Power Hooks for Top of Climb, Rolling Takeoff and Sea Level Static Operating Conditions.

TABLE 3.-PRINCIPLE MECHANICAL DESIGN PARAMETERS

\begin{tabular}{|c|}
\hline Mechanical design parameter \\
\hline 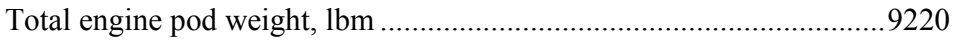 \\
\hline Counter-rotating propeller weight, $1 \mathrm{bm}$....................... \\
\hline 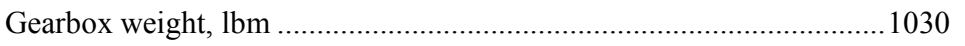 \\
\hline 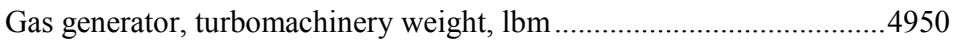 \\
\hline 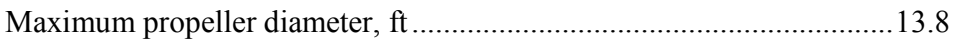 \\
\hline Nacelle diameter, $\mathrm{ft}$ \\
\hline 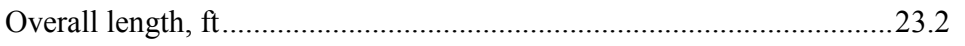 \\
\hline 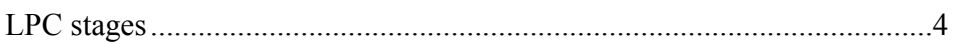 \\
\hline HPC stages......................... \\
\hline HPT stages............. \\
\hline 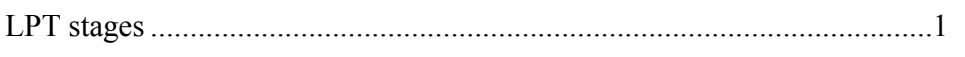 \\
\hline Power turbine stages ......................... \\
\hline 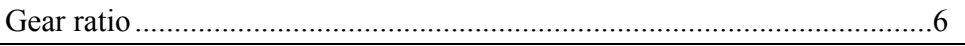 \\
\hline
\end{tabular}




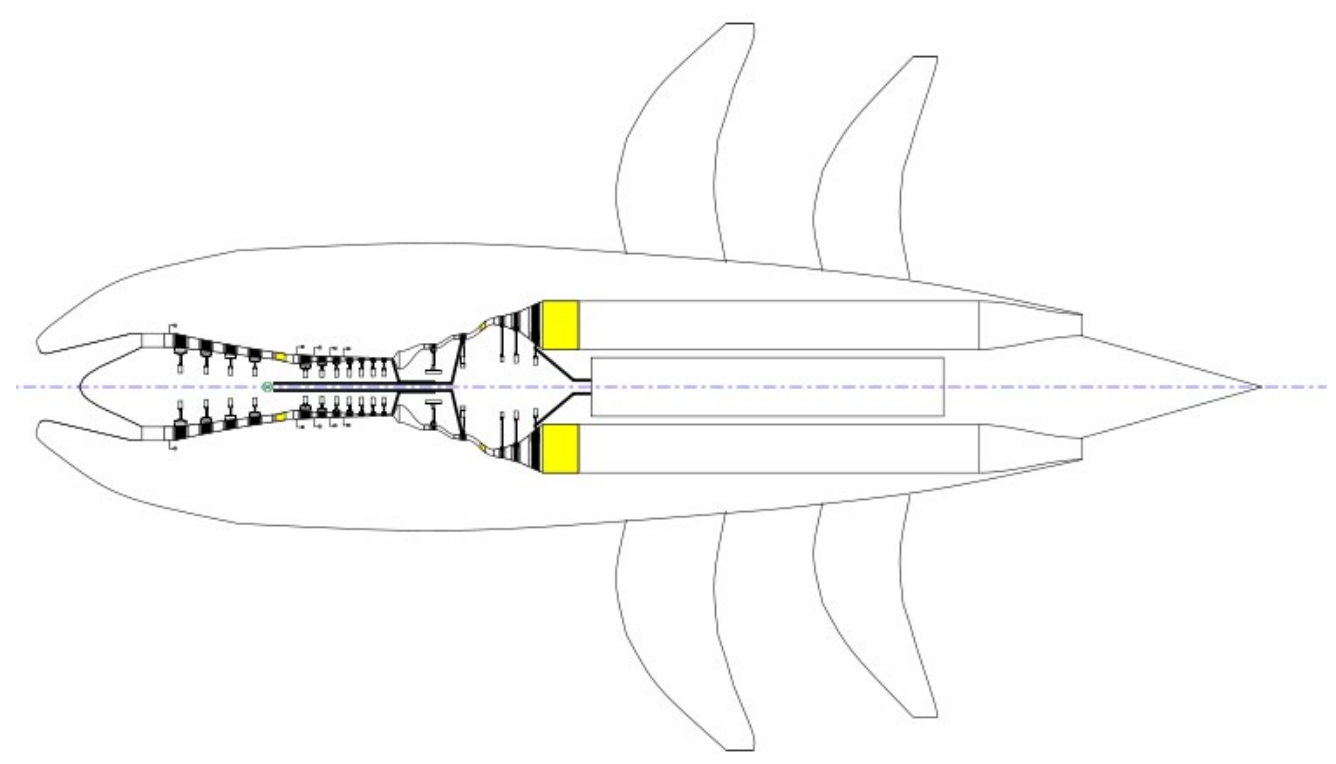

Figure 9.-Notional Cross-Section of the Open Rotor Engine.

\section{Comparison to NASA Advanced Turbofan Study}

The open rotor engine study described in this paper is the latest in a series of NASA studies which have examined future propulsion system concepts for an ASAT aircraft. As such, the open rotor model development followed a similar modeling process and applied the same technology assumptions as the previous studies. Therefore, a comparison can be made between engines of the previous studies and the open rotor engine presented in this paper.

The previous studies on advanced propulsion systems for ASAT aircraft focused on modeling geared and direct drive turbofans as described in Reference 2. In the most recent phase of the turbofan study, two engines, one geared and one direct drive, were identified as desirable due to their system level characteristics. A geared turbofan with a high pressure ratio LPC and a design point fan pressure ratio of 1.5 was determined to be the engine that resulted in the lowest block fuel (and therefore the lowest operating cost) required for the selected mission. The second engine identified in the study was a direct drive configuration with a low pressure ratio LPC and design point fan pressure ratio of 1.7. This engine resulted in the lowest aircraft takeoff gross weight which is often used as a surrogate parameter in conceptual design for the purchase cost of the aircraft. Because of the desirable features of these two engines, they were selected for comparison to the open rotor engine described in this paper.

Key engine characteristics for the geared turbofan, direct drive turbofan and open rotor engines are presented in Table 4. At the top-of-climb flight condition, all three engines produce a similar amount of thrust (see table note regarding differences in top-of-climb flight conditions between the turbofans and open rotor) with the same overall pressure ratio. While all three engines produce similar amounts of thrust, the open rotor engine has a lower thrust specific fuel consumption. A lower TSFC generally translates to less fuel required to fly the same mission with the aircraft. At the sea level static operating point, the open rotor engine performance and environmental characteristics are noticeably different than both of the turbofan engines. First, the open rotor engine produces almost $4000 \mathrm{lb}$ of additional thrust. The higher thrust at sea level is again evidence that the open rotor engine is oversized for takeoff because of the requirements and constraints placed on the engine at the top-of-climb design point. The open rotor engine also has a lower TSFC at the sea level static flight condition compared to both turbofans, indicating lower fuel consumption for the open rotor engine during takeoff. 
TABLE 4.-COMPARISON OF ADVANCED TURBOFAN AND OPEN ROTOR ENGINES

\begin{tabular}{|l|l|c|c|c|}
\hline \multicolumn{2}{|c|}{ Engine parameter } & $\begin{array}{c}\text { Geared } \\
\text { turbofan }\end{array}$ & $\begin{array}{c}\text { Direct drive } \\
\text { turbofan }\end{array}$ & Open rotor \\
\hline \multirow{3}{*}{$\begin{array}{l}\text { Top of climb, } \\
\text { M0.80, 35000 ft }\end{array}$} & OPR & 42 & 42 & 42 \\
\cline { 2 - 5 } & Net thrust, lbf & 5000 & 5000 & 4960 \\
\cline { 2 - 5 } & TSFC, lbm/hr/lbf & 0.502 & 0.525 & 0.441 \\
\hline \multirow{2}{*}{$\begin{array}{l}\text { Sea level static, } \\
\text { M0.0, 0 ft, ISA+27 }{ }^{\circ} \mathrm{F}\end{array}$} & OPR & 32.7 & 33.8 & 29.4 \\
\cline { 2 - 5 } & Net thrust, lbf & 23400 & 22700 & 27300 \\
\cline { 2 - 5 } & TSFC, lbm/hr/lbf & 0.257 & 0.290 & 0.158 \\
\hline Fan or propeller diameter, ft & 6.2 & 5.5 & 13.8 \\
\hline Nacelle maximum diameter, ft & 7.6 & 6.7 & 5.6 \\
\hline Total engine pod weight, lbm & 6630 & 6100 & 9220 \\
\hline
\end{tabular}

${ }^{a}$ Note that the open rotor engine was designed for a top of climb flight condition of M0.78 at $35000 \mathrm{ft}$ in order to match propeller design characteristics. This table presents open rotor engine performance characteristics at M0.80, $35000 \mathrm{ft}$ for top of climb for comparison to the previously designed turbofan engines of Reference 2.

Table 4 also provides a comparison of some of the major mechanical design characteristics of the three engines. The open rotor engine is much larger in diameter as the propellers are almost twice the diameter of the turbofan nacelles. Furthermore, the open rotor engine weight is significantly heavier, primarily due to the large propellers. The weight and size of the open rotor will partially offset the benefit of lower fuel burn for this engine compared to the turbofans. An aircraft with an open rotor engine will likely have a higher empty weight (due to the higher engine weight), but the aircraft would require less fuel to complete the mission. As a result, the overall aircraft takeoff gross weight would likely be similar between turbofan and open rotor powered aircraft (Ref. 16).

\section{Conclusion}

NASA's Subsonic Fixed Wing and Environmentally Responsible Aviation Programs are both interested in developing technologies which will reduce the environmental impact of future aircraft. The open rotor engine is of interest to both of these programs due to its potential to reduce fuel consumption and emissions of NOx near airports. In order to assess the potential impact of an open rotor engine on an advanced single aisle aircraft, modeling capabilities have been developed by NASA to predict the performance and weight characteristics of open rotor engines. The initial development of open rotor modeling capabilities was described in a previous paper.

Following the initial model development, further improvements to open rotor modeling capabilities were made and presented in this paper. First, propeller maps representative of modern blade designs were developed using data collected in recent wind tunnel experiments by NASA and General Electric. Second, the model was transitioned to a geared open rotor architecture as the geared configuration provided better or equivalent performance at a lower overall engine weight. Next, a new power management strategy was implemented to control the blade pitch angles throughout the flight envelope. The new constant tip speed strategy replaced the assumed blade angle schedule and provided a more realistic approximation of how an open rotor engine would be operated. Lastly, weight estimation techniques were developed for the counter-rotating propellers and the gearbox. These methods were then implemented to determine the mechanical design characteristics of an open rotor engine.

Using the modeling capabilities summarized in this paper, an open rotor engine model was created. This engine was sized using a MDP approach to power an advanced single aisle transport aircraft. The open rotor engine model predicted a low thrust specific fuel consumption throughout the flight envelope. In addition, a large thrust lapse resulted from the MDP design process producing an engine that is oversized at rolling takeoff and sea level static flight conditions. The open rotor weight was estimated to be $9220 \mathrm{lb}$, with about half of the engine pod weight coming from the propellers and gearbox. Lastly, the open rotor model results were compared to similar result for both geared and direct drive turbofans. The 
open rotor system is predicted to have better thrust specific fuel consumption compared to both turbofans. However, the turbofan engines are both about $3000 \mathrm{lb}$ lighter than the open rotor engine.

While a direct comparison of the open rotor, geared turbofan and direct drive turbofan can provide some insight into the benefits of each, the impact of the engine can only be truly assessed when they are integrated with a full aircraft. By integrating the engine with an aircraft, total fuel burn, emissions, and noise estimates can be made. An assessment of an entire aircraft system for these metrics was beyond the scope of this paper. However, the open rotor engine described in this paper has been integrated with an advanced aircraft to evaluate the potential benefit of this engine. Overall, the open rotor powered aircraft is predicted to have 36 percent lower fuel consumption than a 1990s reference baseline aircraft (Ref. 16).

Additionally, the open rotor aircraft is estimated to have a $13 \mathrm{~dB}$ cumulative margin to Stage 4 noise regulations (Ref. 16). While there is uncertainty in both of these estimates, they indicate that an open rotor engine may be able to meet the future propulsion requirements of a single aisle transport aircraft.

\section{References}

1. Del Rosario, R., "NASA Subsonic Fixed Wing Project Overview," 2012 NASA Fundamental Aeronautics Program Technical Conference, Renaissance Cleveland Hotel, Cleveland, 14 March 2012, Lecture.

2. Guynn, M., Berton, J., Fisher, K., Haller, W., Tong, M. and Thurman, D., "Refined Exploration of Turbofan Design Options for an Advanced Single-Aisle Transport," NASA/TM-2011-216883, 2011.

3. Hager, Roy D., and Vrabel, Deborah, “Advanced Turboprop Project”, NASA SP-495, 1988.

4. Van Zante, D., "Open Rotor Noise Research in the US." X-Noise Workshop, Lausanne, Switzerland, 18 March 2011, Lecture.

5. Parry, A. B., "Current Open Rotor Noise Research in EU," X-Noise Workshop, Lausanne, Switzerland, 18 March 2011, Lecture.

6. Hendricks, E. "Development of an Open Rotor Cycle Model in NPSS Using a Multi-Design Point Approach." Presented at the 2011 ASME Turbo Expo in Vancouver, Canada. GT2011-46694.

7. Guynn, M.; Berton, J.; Hendricks, E.; Tong, M.; Haller, W.; and Thurman, D., "Initial Assessment of Open Rotor Propulsion Applied to an Advanced Single-Aisle Aircraft," AIAA-2011-7058, 10th

AIAA Aviation Technology, Integration, and Operations (ATIO) Conference, September, 2011, Virginia Beach, VA, 20-22 September, 2011.

8. NPSS User Guide Software Release: NPSS 1.6.5.

9. Hoff, G.E. et al., "Experimental Performance and Acoustic Investigation of Modern, Counterrotating Blade Concepts," NASA-CR-185158, 1990.

10. Reid, C. "Overview of Flight Testing of GE Aircraft Engines UDF Engine." AIAA-88-3082.

11. Norris, G., "Open Return: General Electric and NASA dust off test rigs from 20 years ago," Aviation Week and Space Technology, 14 July 2008.

12. Onat, E. and Klees, G.W., "A Method to Estimate Weight and Dimensions of Large and Small Gas Turbine Engines," NASA CR-159481, 1979.

13. Tong, M.T., Halliwell, I., Ghosn, L.J., "A Computer Code for Gas Turbine Engine Weight and Life Estimation," ASME Journal of Engineering for Gas Turbine and Power, volume 126, no. 2, pp.265270, April 2004.

14. Tong, M.T., Naylor, B.A., "An Object-Oriented Computer Code for Aircraft Engine Weight Estimation," GT2008-50062, ASME Turbo-Expo 2008, June 9-13, 2008.

15. Weisbnch, A. L., Godston, J. and Bradle, E.S., "Technology and Benefits of High Speed Aircraft Counter Rotation Propellers," NASA CR-168258, 1982.

16. Guynn, M., "Open Rotor Propulsion Assessment for Advanced Single-Aisle Aircraft," 2012 NASA Fundamental Aeronautics Program Technical Conference, Renaissance Cleveland Hotel, Cleveland, 14 March 2012, Lecture. 


\begin{tabular}{|c|c|c|c|c|c|}
\hline \multicolumn{5}{|c|}{ REPORT DOCUMENTATION PAGE } & $\begin{array}{l}\text { Form Approved } \\
\text { OMB No. 0704-0188 }\end{array}$ \\
\hline \multicolumn{6}{|c|}{ 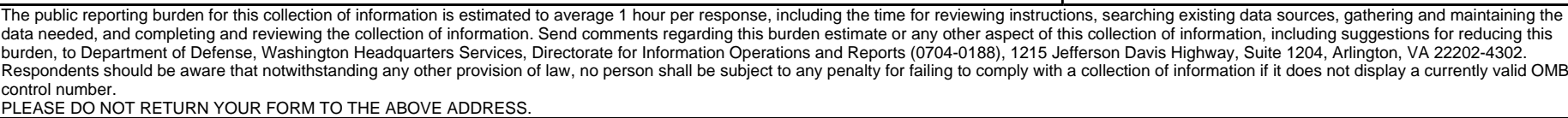 } \\
\hline \multicolumn{2}{|c|}{$\begin{array}{l}\text { 1. REPORT DATE (DD-MM-YYYY) } \\
01-09-2012\end{array}$} & \multicolumn{3}{|c|}{$\begin{array}{l}\text { 2. REPORT TYPE } \\
\text { Technical Memorandum }\end{array}$} & 3. DATES COVERED (From - To) \\
\hline \multirow{3}{*}{\multicolumn{5}{|c|}{$\begin{array}{l}\text { 4. TITLE AND SUBTITLE } \\
\text { Performance and Weight Estimates for an Advanced Open Rotor Engine }\end{array}$}} & 5a. CONTRACT NUMBER \\
\hline & & & & & 5b. GRANT NUMBER \\
\hline & & & & & 5c. PROGRAM ELEMENT NUMBER \\
\hline \multirow{3}{*}{\multicolumn{5}{|c|}{$\begin{array}{l}\text { 6. AUTHOR(S) } \\
\text { Hendricks, Eric, S.; Tong, Michael, T. }\end{array}$}} & 5d. PROJECT NUMBER \\
\hline & & & & & 5e. TASK NUMBER \\
\hline & & & & & $\begin{array}{l}\text { 5f. WORK UNIT NUMBER } \\
\text { WBS 561581.02.08.03.42.03 }\end{array}$ \\
\hline \multicolumn{5}{|c|}{$\begin{array}{l}\text { 7. PERFORMING ORGANIZATION NAME(S) AND ADDRESS(ES) } \\
\text { National Aeronautics and Space Administration } \\
\text { John H. Glenn Research Center at Lewis Field } \\
\text { Cleveland, Ohio 44135-3191 }\end{array}$} & $\begin{array}{l}\text { 8. PERFORMING ORGANIZATION } \\
\text { REPORT NUMBER } \\
\text { E-18415 }\end{array}$ \\
\hline \multirow{2}{*}{\multicolumn{5}{|c|}{$\begin{array}{l}\text { 9. SPONSORING/MONITORING AGENCY NAME(S) AND ADDRESS(ES) } \\
\text { National Aeronautics and Space Administration } \\
\text { Washington, DC 20546-0001 }\end{array}$}} & $\begin{array}{l}\text { 10. SPONSORING/MONITOR'S } \\
\text { ACRONYM(S) } \\
\text { NASA }\end{array}$ \\
\hline & & & & & $\begin{array}{l}\text { 11. SPONSORING/MONITORING } \\
\text { REPORT NUMBER } \\
\text { NASA/TM-2012-217710 }\end{array}$ \\
\hline \multicolumn{6}{|c|}{$\begin{array}{l}\text { 12. DISTRIBUTION/AVAILABILITY STATEMENT } \\
\text { Unclassified-Unlimited } \\
\text { Subject Category: } 07 \\
\text { Available electronically at http://www.sti.nasa.gov } \\
\text { This publication is available from the NASA Center for AeroSpace Information, 443-757-5802 }\end{array}$} \\
\hline \multicolumn{6}{|c|}{ 13. SUPPLEMENTARY NOTES } \\
\hline \multicolumn{6}{|c|}{$\begin{array}{l}\text { 14. ABSTRACT } \\
\text { NASA's Environmentally Responsible Aviation Project and Subsonic Fixed Wing Project are focused on developing concepts and } \\
\text { technologies which may enable dramatic reductions to the environmental impact of future generation subsonic aircraft. The open rotor } \\
\text { concept (also historically referred to an unducted fan or advanced turboprop) may allow for the achievement of this objective by reducing } \\
\text { engine fuel consumption. To evaluate the potential impact of open rotor engines, cycle modeling and engine weight estimation capabilities } \\
\text { have been developed. The initial development of the cycle modeling capabilities in the Numerical Propulsion System Simulation (NPSS) } \\
\text { tool was presented in a previous paper. Following that initial development, further advancements have been made to the cycle modeling and } \\
\text { weight estimation capabilities for open rotor engines and are presented in this paper. The developed modeling capabilities are used to predict } \\
\text { the performance of an advanced open rotor concept using modern counter-rotating propeller designs. Finally, performance and weight } \\
\text { estimates for this engine are presented and compared to results from a previous NASA study of advanced geared and direct-drive turbofans. }\end{array}$} \\
\hline \multicolumn{6}{|c|}{$\begin{array}{l}\text { 15. SUBJECT TERMS } \\
\text { Propellers; Contrarotating propellers; Turboprop engines; Gas turbine engines }\end{array}$} \\
\hline \multicolumn{3}{|c|}{ 16. SECURITY CLASSIFICATION OF: } & $\begin{array}{l}\text { 17. LIMITATION OF } \\
\text { ABSTRACT }\end{array}$ & $\begin{array}{l}\text { 18. NUMBER } \\
\text { OF }\end{array}$ & $\begin{array}{l}\text { 19a. NAME OF RESPONSIBLE PERSON } \\
\text { STI Help Desk (email:help@sti.nasa.gov) }\end{array}$ \\
\hline $\begin{array}{l}\text { a. REPORT } \\
\text { U }\end{array}$ & $\begin{array}{l}\text { b. ABSTRACT } \\
\text { U }\end{array}$ & $\begin{array}{l}\text { c. THIS } \\
\text { PAGE } \\
\text { U }\end{array}$ & UU & $\begin{array}{l}\text { PAGES } \\
20\end{array}$ & $\begin{array}{l}\text { 19b. TELEPHONE NUMBER (include area code) } \\
443-757-5802\end{array}$ \\
\hline
\end{tabular}



